\title{
PARAMETRIC STUDY FOR INFLUENCE OF INPUT PARAMETERS FOR ANALYSIS OF FIBRE REINFORCED CONCRETE SLAB-SOIL INTERACTION
}

\author{
Zuzana MARCALIKOVA ${ }^{1}$, Zdenka NEUWIRTHOVA², Radim CAJKA ${ }^{3}$ \\ ${ }^{1}$ Department of Structures, Faculty of Civil Engineering, VSB-Technical University of Ostrava, \\ Ludvika Podeste 1875/17, 70833 Ostrava - Poruba, Czech Republic \\ ${ }^{2}$ Department of Structures, Faculty of Civil Engineering, VSB-Technical University of Ostrava, \\ Ludvika Podeste 1875/17, 70833 Ostrava - Poruba, Czech Republic \\ ${ }^{3}$ Department of Structures, Faculty of Civil Engineering, VSB-Technical University of Ostrava, \\ Ludvika Podeste 1875/17, 70833 Ostrava - Poruba, Czech Republic \\ zuzana.marcalikova@vsb.cz, zdenka.neuwirthova@,vsb.cz, radim.cajka@,vsb.cz
}

DOI: 10.31490/tces-2018-0012

\begin{abstract}
For geotechnical engineering and design of foundation elements of structures is important to properly determine the stress-deformation state of the subsoil. The calculation is most often done using the finite element method and the computational models. This article includes the parametric study for the selected type of concrete foundation structures. The article focuses attention to the calculation of the deformation of the slab with respect to the influences of individual input parameters (e.g. stiffness of concrete and subsoil, boundary condition, size of elements). Calculations are performed for two concrete types and three soil variants.
\end{abstract}

\section{Keywords}

Geotechnical engineering, foundation elements, structures, subsoil, finite element method, 3D computational model, concrete, calculation.

\section{Introduction}

Analysis of the concrete structure in interaction with the subsoil is a complex computational task and research area [1], [2]. This area has a great deal of attention in the research in the world [3], [4], [5]. For this task is also typical influence of physical and structural nonlinearity. This is particularly the case when the construction collapse and total bearing capacity are monitored. With these reasons, it is important experiments research [6], [7], [8]. Subsequently, it is possible to use appropriate numerical and design methods. Design models of punching of flat slabs and geotechnical tasks are being surveyed and discussed [9], [10], [11]. To achieve comprehensible numerical results, the core of problem is to be understood. It is advisable to initially solve the problem as linear and to know the basic behavior of the structure. In the numerical task being solved, the ratio is the stiffness of the concrete structure and the subsoil and the model uncertainty. Numerical calculations of deformations for the concrete slab in interaction with the subsoil are also influenced by the choice of ground and soil model. There are a number of design and numerical methods to solve the task of interacting slab with the subsoil. Typical cases include the use of analytical methods that often simplify the solution. The limitation is that it is not possible to change the properties of the subsoil model in parts or it is not possible to examine closely the collapse of the structure. On the other hand, it is possible to use the finite element method [12], [13]. The Finite Element Method was used in this paper through the ANSYS computational program [14]. In this method and task, however, a whole range of options and parameterization of the computational model was created. With this advanced calculation method, it is possible to take into account the actual behavior of the problem solved. The computational model is based on discretization of finite elements and material models. Some approaches use advanced methods and calculations are in [15], [16], [17]. This article aims at this research area.

\section{Experimental testing}

An integral part of the study of interaction between the concrete slab and the subsoil is experimental testing. VSB 
- Technical University, Faculty of Civil Engineering [18] has for this purpose specialized equipment/device. This equipment has of a test frame with a hydraulic press with a capacity of $1000 \mathrm{kN}$. This test equipment/device is connected to a universal measurement panel for deformation, strain and force. Concrete slabs can have a size up to $2000 \times 2000 \mathrm{~mm}$ and a typical thickness of 100 to $200 \mathrm{~mm}$. Typical tested concrete slab during and after the test is shown in the Figures 1 and 2. The subsoil has typical $E_{\text {def }}$ values of 3 to $33 \mathrm{MPa}$.

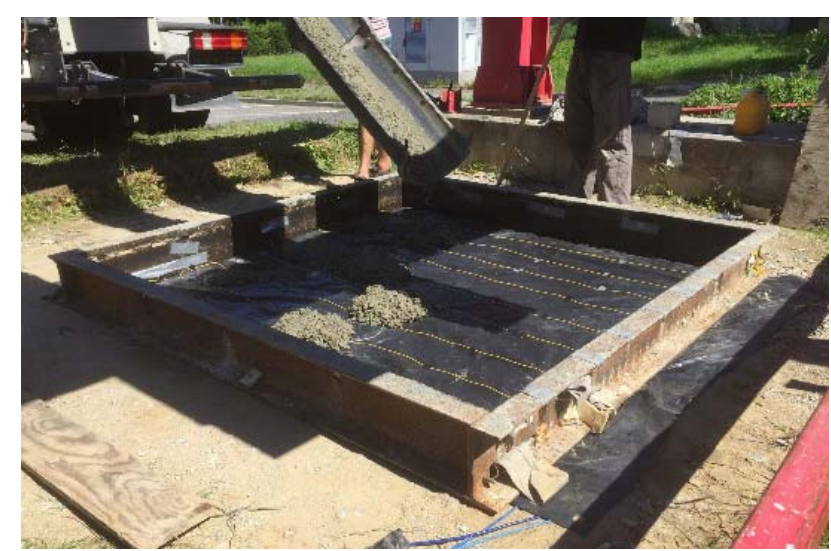

Fig. 1: Concrete slab-production

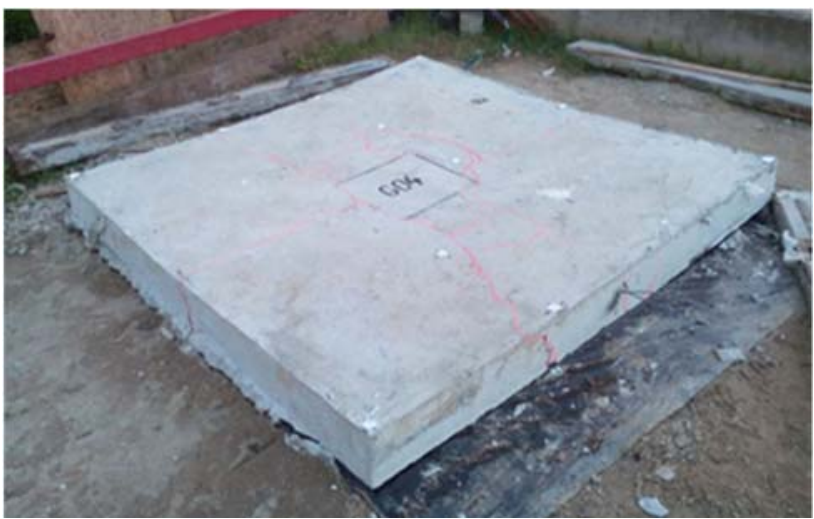

Fig. 2: Concrete slab - after the test

With the development of material research, there are a number of designs used. Selected experiments and calculations for solved slabs are in [19] and [20]. Typically, fibre concrete is show for example. This material has a number of improved properties. For example: tensile strength and ductility. For the already implemented experimental program, computational models and analyses are created that appropriately respect the actual behaviour. Concrete slabs also contain from 0 to $75 \mathrm{~kg} / \mathrm{m}^{3}$ of fibre [21]. For this series of fibre concrete slabs, the total bearing capacity of the slabs was in the range of 300 to $700 \mathrm{kN}$. Details of the experimental program with fibre concrete slabs are given [21]. The fibre concrete slab G02 is selected for a parametric study. This concrete slab had a maximum total bearing capacity of up to about $500 \mathrm{kN}$. The loading record of during the test is shown in Figure 3. Further data of experiments on specialized equipment/device and calculations has [22]. Typical used fiber for concrete slab are shown in Figure 4.

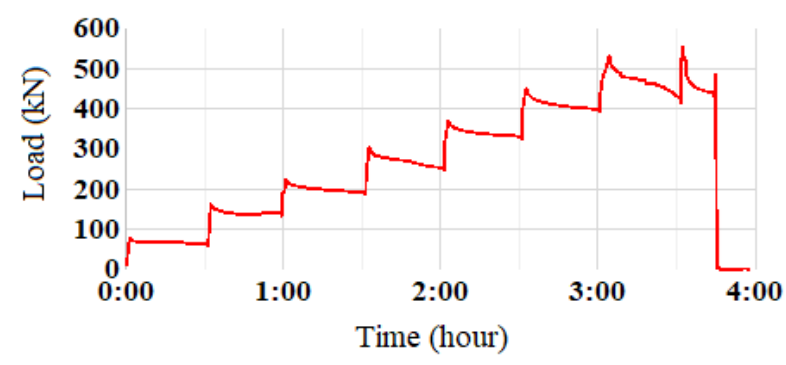

Fig. 3: Loading record of during the test [21]

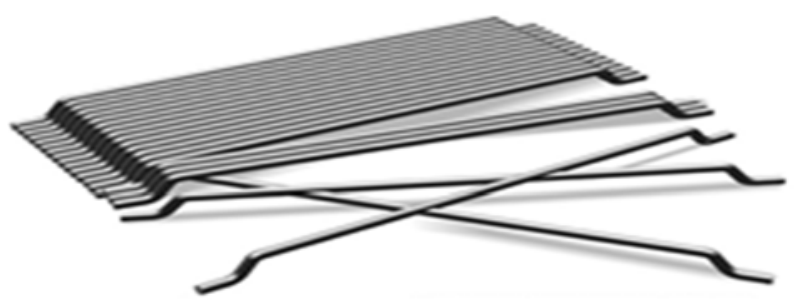

Fig. 4: Fiber Dramix 3D 65/60 BG [21], [23]

\section{Parametric study}

The subject of the parametric study is to evaluate the influence of the input variables on the calculation. The study solves the size of the deformation for different combinations of the modulus of elasticity of the concrete and the subsoil, the size of the finite element and the depth of the subsoil. The modelling task represents a typical case of experiment of concrete slab for specialized equipment. Parametric study for the subsoil model considers depths of 4, 6 and $8 \mathrm{~m}$. The calculation was done in ANSYS [14]. The solved task offers several possibilities of creating a computational model. The task is also symmetrical for both axes. It is simplest to use only the beam model on the subsoil. A more advanced choice is a planar and spatial computational model. With regard to the parameters calculation and the computational complexity is selected for computational model used finite element PLANE 182 (Figure 5). The computational model consists of the final elements of PLANE 182 which will adequately capture the solved area of the parametric study. PLANE182 [14] is used to model 2-D solid structures. It can be used as either a plane element (plane stress, plane strain or generalized plane strain) or an axisymmetric element with or without torsion. In most cases, the element is defined by four nodes with two degrees of freedom at each node: translations in the nodal $x$ and $y$ directions [14]. 


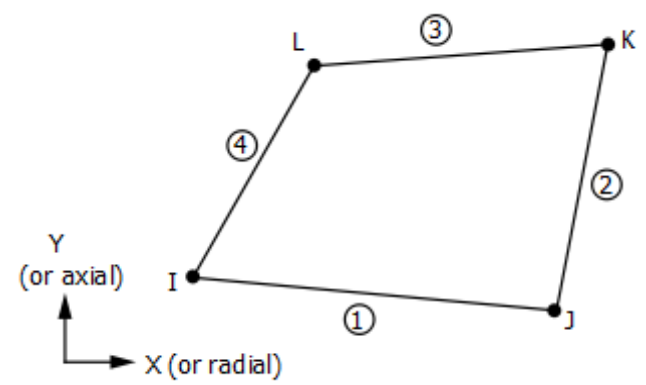

Fig. 5: PLANE182 Geometry [14]
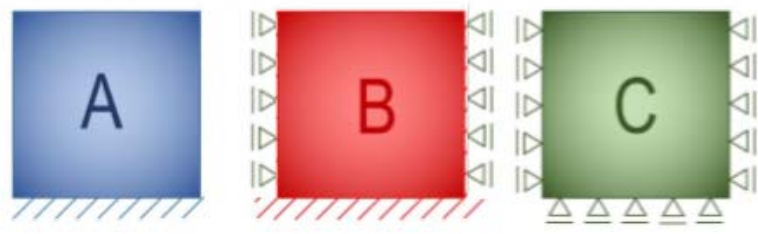

Fig. 6: Boundary conditions

The basic size of the finite element is set to the line size of $0,1 \mathrm{~m}$. Additionally a comparison of the influence of the size of the finite element is performed for the selected case of the calculation model. For the basic part of the study a computational model with parameters is chosen: the modulus of elasticity of the concrete is $28 \mathrm{GPa}$ and the base has a stiffness of 5 to $35 \mathrm{MPa}$.

\subsection{Influence of boundary conditions}

The first comparison presents the effect of boundary conditions. The variance of the boundary conditions is shown in Fig. 6. The calculation is performed for the modulus of elasticity for concrete $28 \mathrm{GPa}$ and subsoil of $15 \mathrm{MPa}$. The depth of the subsoil is $8 \mathrm{~m}$. The results are shown in Table 1.

Tab.1: Vertical deformation - Boundary conditions

\begin{tabular}{|c|c|c|c|}
\hline \multirow{2}{*}{28 GPa / 15 MPa } & \multicolumn{4}{|c|}{ Deformation [mm] } \\
\cline { 2 - 4 } & \multicolumn{3}{|c|}{ Boundary conditions } \\
\hline Depth [m] & A & B & C \\
\hline Top surface of concrete & 26.16 & 24.98 & 24.99 \\
\hline Top surface of subsoil (0) & 26.15 & 24.97 & 24.98 \\
\hline $\mathbf{2}$ & 15.45 & 14.44 & 14.42 \\
\hline $\mathbf{4}$ & 8.62 & 8.06 & 8.09 \\
\hline $\mathbf{6}$ & 3.75 & 3.66 & 3.71 \\
\hline $\mathbf{8}$ & 0.00 & 0.00 & 0.00 \\
\hline
\end{tabular}

\subsection{Influence of element size}

A comparison of the influence of the size of finite element was also performed. The calculation has three variants. The finite elements have an edge size of $0.025 ; 0.1 ; 0.25 \mathrm{~m}$ The results are shown in Tab. 2. Percentage is given as compared to the base size of the finite element of $0.1 \mathrm{~m}$.
Tab.2: Vertical deformation - Size of finite element

\begin{tabular}{|c|c|c|c|}
\hline \multirow{2}{*}{ Mesh } & \multicolumn{3}{|c|}{ Deformation [mm] } \\
\cline { 2 - 4 } & \multicolumn{3}{|c|}{ Finite element [m] } \\
\hline Depth $[\mathbf{m}]$ & $\mathbf{0 . 2 5 0}$ & $\mathbf{0 . 1 0 0}$ & $\mathbf{0 . 0 2 5}$ \\
\hline Top surface of concrete & 25.573 & 26.160 & 26.448 \\
\hline \% & $97.756 \%$ & - & $101.101 \%$ \\
\hline Top surface of subsoil (0) & 25.572 & 26.151 & 26.432 \\
\hline \% & $97.786 \%$ & - & $101.075 \%$ \\
\hline
\end{tabular}

\subsection{Influence of concrete stiffness}

Another part of the study solves the stiffness of concrete material for $8 \mathrm{~m}$ deep subsoil. Two variants of 28 and $50 \mathrm{GPa}$ are considered. It is for calculation: concrete modulus of elasticity of $50 \mathrm{GPa}, 35 \mathrm{MPa}$ and subsoil track bed depth of $8 \mathrm{~m}$. The fig. 7 show details on deformation information. This is a calculation: modulus of elasticity of concrete $50 \mathrm{GPa}$ and subsoil $35 \mathrm{MPa}$ and depth $8 \mathrm{~m}$.
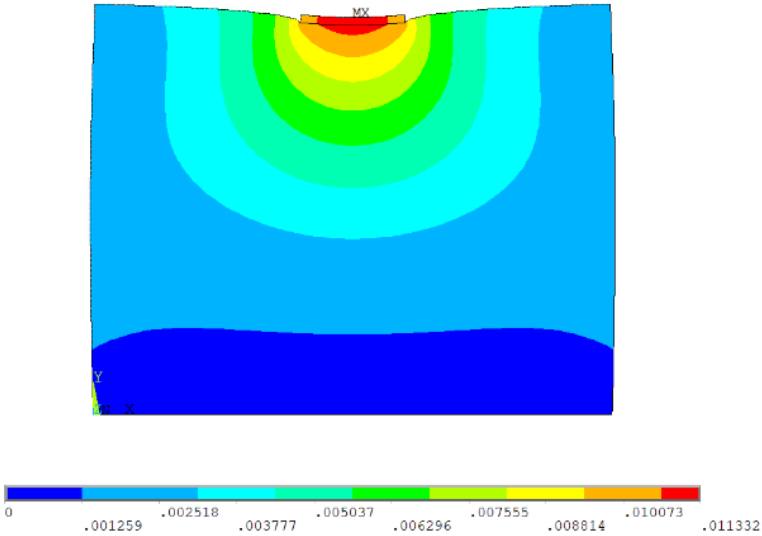

Fig. 7: Vertical deformation $(11.332 \mathrm{~mm})$ for concrete $(50 \mathrm{GPa})$ and subsoil (35 MPa)

A summary comparison is shown in Table 3 . Differences in deformations are small.

Tab.3: Vertical deformation - Modulus of elasticity concrete 28 and $50 \mathrm{GPa}$

\begin{tabular}{|c|c|c|c|}
\hline \multirow{5}{*}{$\begin{array}{c}\mathbf{5 0} \\
\text { GPa }\end{array}$} & \multicolumn{3}{|c|}{ Deformation [mm] } \\
\cline { 2 - 4 } $\begin{array}{c}\text { Depth } \\
{[\mathbf{m}]}\end{array}$ & $\begin{array}{c}\mathbf{3 5} \\
\text { MPa }\end{array}$ & $\begin{array}{c}\mathbf{1 5} \\
\text { MPa }\end{array}$ & $\begin{array}{c}\mathbf{5} \\
\text { MPa }\end{array}$ \\
\hline Conc. $*$ & 11.33 & 25.72 & 75.91 \\
\hline $\mathbf{0}$ & 11.33 & 25.71 & 75.90 \\
\hline $\mathbf{2}$ & 6.62 & 15.44 & 46.28 \\
\hline $\mathbf{4}$ & 3.69 & 8.63 & 25.89 \\
\hline $\mathbf{6}$ & 1.61 & 3.76 & 11.27 \\
\hline $\mathbf{8}$ & 0.00 & 0.00 & 0.00 \\
\hline
\end{tabular}

\begin{tabular}{|c|c|c|c|}
\hline \multirow{2}{*}{$\begin{array}{c}\mathbf{6 P} \\
\text { GPa }\end{array}$} & \multicolumn{3}{|c|}{ Deformation [mm] } \\
\cline { 2 - 4 } $\begin{array}{c}\text { Depth } \\
\text { [m] }\end{array}$ & $\begin{array}{c}\mathbf{3 5} \\
\text { MPa }\end{array}$ & $\begin{array}{c}\mathbf{1 5} \\
\text { MPa }\end{array}$ & $\begin{array}{c}\mathbf{5} \\
\text { MPa }\end{array}$ \\
\hline Conc. $*$ & 11.68 & 26.16 & 76.41 \\
\hline $\mathbf{0}$ & 11.68 & 26.15 & 76.40 \\
\hline $\mathbf{2}$ & 6.63 & 15.45 & 46.29 \\
\hline $\mathbf{4}$ & 3.69 & 8.62 & 25.89 \\
\hline $\mathbf{6}$ & 1.61 & 3.75 & 11.27 \\
\hline $\mathbf{8}$ & 0.00 & 0.00 & 0.00 \\
\hline
\end{tabular}




\subsection{Influence of elasticity of subsoil}

The last part of the parametric study deals with the comparison of the modulus of elasticity and the depth of the subsoil. The modulus of elasticity of the concrete is $28 \mathrm{GPa}$. The modulus of elasticity of the subsoil has values of 5.15 and $35 \mathrm{MPa}$. The depth of the subsoil is 4, 6 and 8 $\mathrm{m}$. The following graph in Figure 8 shows the dependence of depth of the subsoil model on the resulting deformations for the elastic modulus of $35 \mathrm{MPa}$.

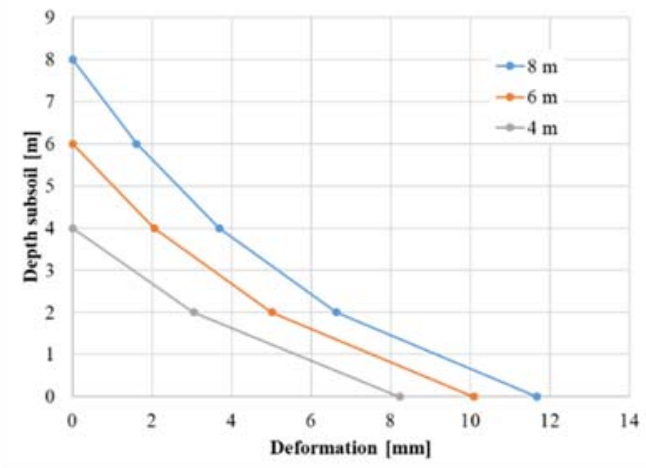

Fig. 8: Vertical deformation $(11.332 \mathrm{~mm})$ for concrete $(50 \mathrm{GPa})$ and subsoil (35 MPa)

The results can also be summarized in Figure 9.

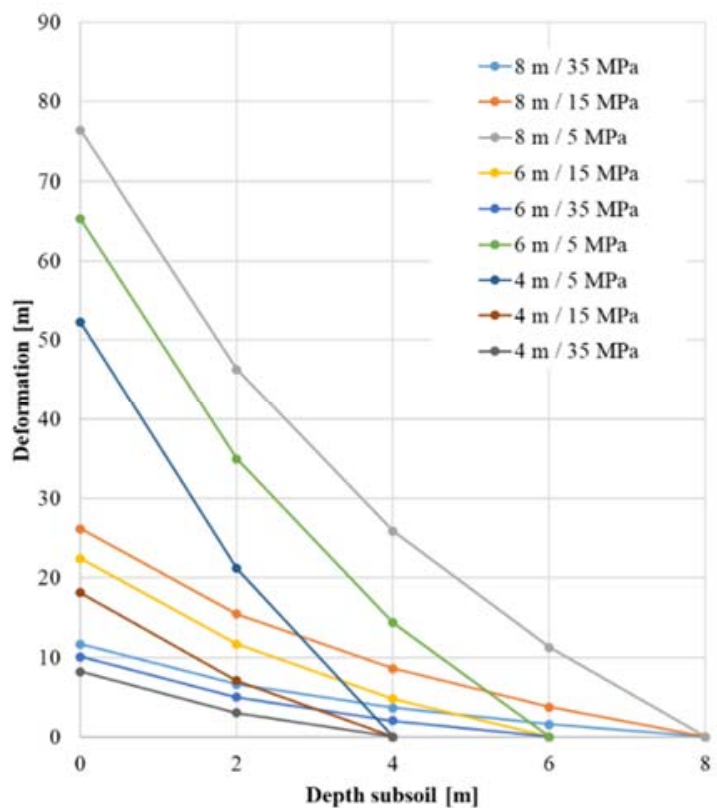

Fig. 9: Vertical deformation ( $\mathrm{mm}$ ) for concrete (28 GPa) and subsoil (5, 15 a $35 \mathrm{MPa})$ and depth $(4 ; 6 ; 8 \mathrm{~m})$

When choosing depths of the subsoil, it is also possible to consider the magnitude/size of the stress. This problem compares tab. 4. Calculations of the deformation as well as the normal stress $\sigma_{\mathrm{y}}$ are shown in the calculations. The calculation is made for the modulus of elasticity of concrete $28 \mathrm{GPa}$ and the modulus of elasticity of subsoil $15 \mathrm{MPa}$.

Tab.4: Vertical deformation and stress $\sigma_{\mathrm{y}}$

\begin{tabular}{|c|c|c|c|c|c|c|}
\hline \multirow{2}{*}{$\begin{array}{c}\mathbf{2 8} \mathbf{~ G P a} / \\
\mathbf{1 5} \mathbf{~ M P a}\end{array}$} & \multicolumn{3}{|c|}{ Calculation model - Depth 6-8 m } & \multicolumn{2}{c|}{$\begin{array}{c}\text { Difference } \\
\text { percentage }\end{array}$} \\
\cline { 2 - 8 } & Def. & Stress $\boldsymbol{\sigma}_{\mathbf{y}}$ & Def. & Stress $\boldsymbol{\sigma}_{\mathbf{y}}$ & Def. & $\begin{array}{c}\text { Stress } \\
\sigma_{\mathbf{y}}\end{array}$ \\
\hline Depth [m] & $\mathbf{m m}$ & $\mathbf{k P a}$ & $\mathbf{m m}$ & $\mathbf{k P a}$ & $\mathbf{\%}$ & $\%$ \\
\hline $\begin{array}{c}\text { Top surface } \\
\text { of concrete }\end{array}$ & 26.16 & $-4,203.00$ & 22.45 & $-4,203.00$ & 1.17 & 1.00 \\
\hline $\begin{array}{c}\text { Top surface } \\
\text { of subsoil (0) }\end{array}$ & 26.15 & -105.01 & 22.44 & -105.20 & 1.17 & 1.00 \\
\hline $\mathbf{2}$ & 15.45 & -61.49 & 11.66 & -62.08 & 1.32 & 0.99 \\
\hline $\mathbf{4}$ & 8.62 & -40.31 & 4.79 & -41.23 & 1.80 & 0.98 \\
\hline $\mathbf{6}$ & 3.75 & -31.38 & 0.00 & -32.23 & - & 0.97 \\
\hline $\mathbf{8}$ & 0.00 & -26.38 & - & - & - & - \\
\hline
\end{tabular}

\section{Discussion with results of experiment}

The parametric study includes a variety of options to access the calculation of the slab and subsoil interaction. For comparing the calculated results, the information from the experiment in Fig. 10 is shown. The orientation of the slab is shown in Fig 11. The maximum measured deformation was $32.01 \mathrm{~mm}$ at point 6 . The finite element method is based on the discretization of the computational model for the finite elements, nodes and integration points. The discretization of a model causes differences in results. The results for the different size of finite elements in the deformation are for the solved task of slab and subsoil few percent.

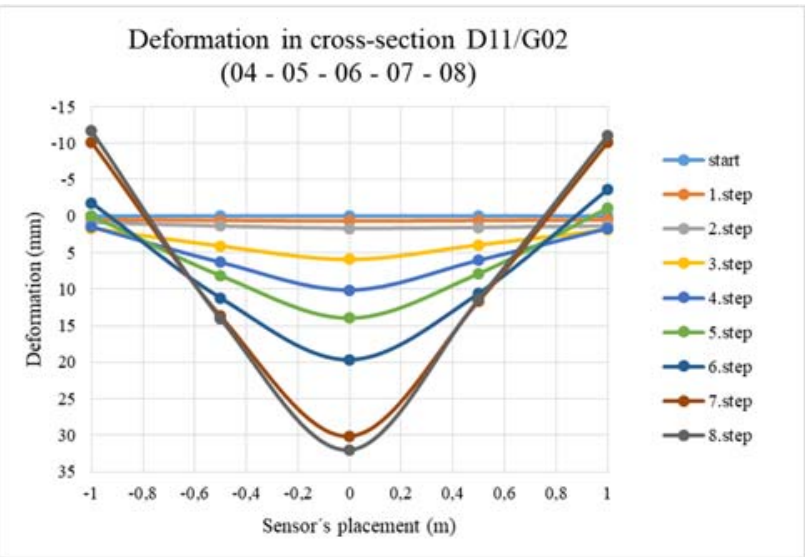

Fig. 10: Vertical deformation in cross-section D11/G02 (mm) 


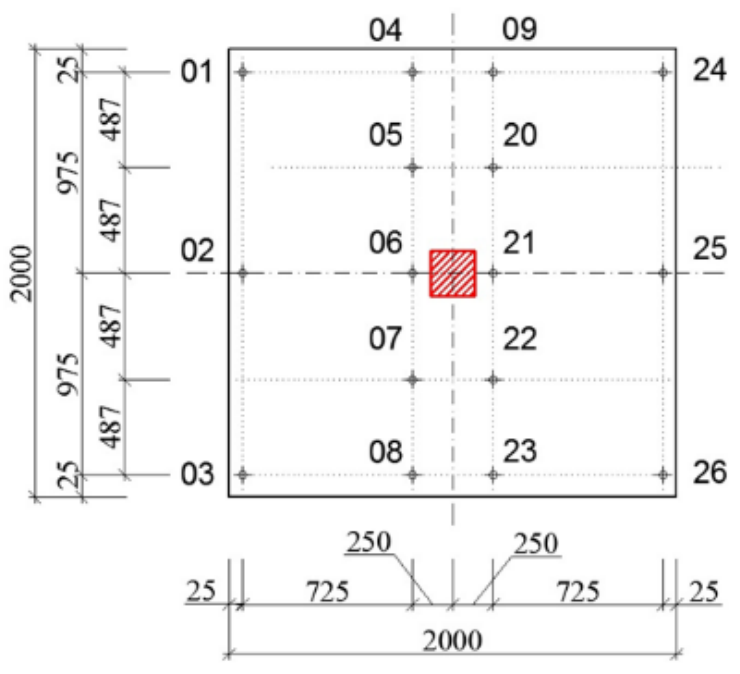

Fig. 11: Orientation of the concrete slab

The largest deformation for variant A was calculated in part of the parametric study containing different boundary conditions. Variant A included the supports only on the bottom of the computational model. Next calculations were performed for this boundary condition variant $\mathrm{A}$. The influence of boundary conditions is considerably smaller than that of input parameters of concrete and subsoil. The ratio between the maximum deformation from the experiment and calculated, was around $78 \%$. In comparison of the calculated deformations there are slight differences in comparison for different stiffness of the concrete. However, this is true for linear calculation. The size of the modulus of elasticity of the subsoil is of much greater importance.

For the calculation of deformation, the worst case is that the modulus of elasticity of the concrete is $28 \mathrm{GPa}$ and the subsoil has a stiffness of only $5 \mathrm{MPa}$. The size of the deformation is $76.41 \mathrm{~mm}$ for this case. Maximal deformations it also depends on the vertical depth of the subsoil model. The largest deformation is for subsoil with a depth of $8 \mathrm{~m}$. By comparing the results of the deformation of the slab and the calculations, it is possible to find the best match of numerical models with a modulus of elasticity of $15 \mathrm{MPa}$ soil. The difference of deformations between the elastic modulus of the concrete 28 and $50 \mathrm{GPa}$ is significantly smaller. In absolute value it is less than $1 \mathrm{~mm}$. The last part of the calculation and study show that the depth of the subsoil affects the calculated deformation significantly more than the stress.

\section{Conclusions}

Interaction between the concrete slab and the subsoil is a complicated task. The calculations and studies have shown that the influence of input parameters can be great. Appropriate use of the subsoil with the modulus elastic with $15 \mathrm{MPa}$ was shown. The concrete difference with the modulus of elasticity 50 or $28 \mathrm{GPa}$ is already small. Particularly in the case of the depth of the subsoil model, the calculated deformations can be very different. For the solved task, it is possible to consider the typical basic recommendation modelling of base depth of subsoil as $2 \mathrm{x}$ base widths of fundament as appropriate. The problem of the computational model is further complicated for cases of more complex geological conditions. This is especially a small modulus of elasticity for the subsoil. The results lead in further next detailed study and research of the interaction of the concrete slab and subsoil. Linear calculation and computational model provide not sufficient accuracy, and it would be preferable to choose a nonlinear model and calculation. Another goal is nonlinear calculation. Further research and numerical modelling is also concentrated with respect to the approach of calculation and using of subsoil models in [24]. However, this also requires more detailed information about the experiments.

\section{Acknowledgements}

This outcome has been achieved with the financial support of the project GACR No. 16-08937S „State of stress and strain of fiber reinforced composites in interaction with the soil environment “.

\section{References}

[1] ABOUTAlEBI, M., ALANI, A., RIZZUTO, J. and D. BECKETT. Structural behaviour and deformation patterns in loaded plain concrete ground-supported slabs. Structural Concrete. 2014, vol. 15, iss. 1, pp. 81-93. DOI:10.1002/suco.201300043.

[2] CAJKA, R., LABUDKOVA, J. and P. MYNARCIK. Numerical solution of soil - foundation interaction and comparison of results with experimental measurements. International Journal of GEOMATE, 2016, vol. 11, iss. 1, pp. 2116-2122.

[3] SUCHARDA, O., SMIRAKOVA, M., VASKOVA, J., MATECKOVA, P., KUBOSEK, J. and R. CAJKA. Punching Shear Failure of Concrete Ground Supported Slab. International Journal of Concrete Structures and Materials. 2018, vol. 12, iss. 1, art. no. 36 .

[4] HALVONIK, J., HANZEL, J. and L. MAJTANOVA. Punching Resistance of Column Basis. Advances and Trends in Engineering Sciences and Technologies II. In: 2nd International Conference on Engineering Sciences and Technologies (ESaT), Jun 29-Jul 01, Slovakia 2016, pp. 93-98, 2017.

[5] HALVONIK, J. and L. MAJTANOVA. Experimental Investigation of the Maximum Punching Resistance of Slab-Column Connections. Slovak Journal of Civil 
Engineering. 2018, vol. 26, iss. 3, pp. 22-28. DOI: $10.2478 /$ sjce-2018-0017

[6] SIBURG C. and J. HEGGER. Experimental investigations on the punching behaviour of reinforced concrete footings with structural dimensions, Structural Concrete. 2014, vol. 15, iss. 3. DOI: $10.1002 /$ suco. 201300083

[7] HEGGER, J., RICKER, M., ULKE, B. and M. ZIEGLER. Investigations on the punching behaviour of reinforced concrete footings. Engineering Structures. 2007, vol. 29, pp. 2233-2241. DOI: $10.1016 /$ j.engstruct.2006.11.012

[8] HEGGER, J., SHERIF, G.A., and M. RICKER. Experimental Investigations on Punching Behaviour of Reinforced Concrete Footings. ACI Structural Journal, 2006, pp. 604-613.

[9] EN 1997-1 (2004) (English): Eurocode7: Geotechnical design - Part 1: General rules [Authority: The European Union Per Regulation 305/2011, Directive 98/34/EC, Directive 2004/18/EC]

[10] CSN EN 1992-1-1, Eurocode 2: Design of concrete structures - Part 1-1: General rules and rules for buildings, 2006.

[11] RICKER, M. and C. SIBURG. Punching shear strength of flat slabs - critical review of Eurocode2 and fib Model Code 2010 design provisions. Structural Concrete, 2016, vol. 17, iss. 3. 1 September 2016, pp. 457-468.

[12] KOLAR, V. and I. NEMEC. Modelling of Soilstructure Interaction. Elsevier, New York, 1989, USA. ISBN 04-449-8859-9.

[13] ZIENKIEWICZ, O.C. The Finite Element Method in Engineering Science. London: McGraw-Hill. 1971.

[14] RELEASE 11 DOCUMENTATION FOR ANSYS, SAS IP, INC., 2018

[15] KOTSOvOU, M.G., KOTSOvOS, M.G. and E. VOUGIOUKAS. Assessment of design methods for punching through numerical experiments. Computers and Concrete. 2016, vol. 17, iss. 3. DOI: 10.12989/cac.2016.17.3.305

[16] IBRAHIM, M. and I.M. METWALLY. Threedimensional finite element analysis of reinforced concrete slabs strengthened with epoxy-bonded steel plates. Advances in Concrete Construction. 2014, vol. 2, iss. 2, pp. 91-108. DOI: 10.12989/acc.2014.2.2.091

[17] HRUBESOVA, E., MOHYLA, M., LAHUTA, H., BUI, T.Q. and P.D. NGUYEN, Experimental analysis of stresses in subsoil below a rectangular fiber concrete slab. Sustainability (Switzerland), 2018, vol. 10 iss. 7, art. no. 2216, DOI: $10.3390 /$ su10072216
[18] CAJKA R., KRIVY V. and D. SEKANINA. Design and Development of a Testing Device for Experimental Measurements of Foundation Slabs on the Subsoil. Transactions of the VSB - Technical University of Ostrava, Civil Engineering Series. 2011, vol. 11 , iss. 1 , pp. $1-5$. DOI: $10.2478 /$ v10160011-0002-2, 2011.

[19] CAJKA, R. and J. LABUDKOVA. Dependence of deformation of a plate on the subsoil in relation to the parameters of the 3D model. International Journal of Mechanic. pp. 208-215, 2014, ISSN: 19984448.

[20] CAJKA, R. Comparison of the calculated and experimentally measured values of settlement and stress state of concrete slab on subsoil. Applied Mechanics and Materials, vol. 501-504, pp. 867-876. Trans Tech Publications, Switzerland, ISSN: 16609336, ISBN: 978-3-03835-005-7, DOI: 10.4028/www.scientific.net/AMM.501-504.867.

[21] SUCHARDA, O., BILEK, V., SMIRAKOVA, M., KUBOSEK, J. and R. CAJKA. Comparative Evaluation of Mechanical Properties of FibreReinforced Concrete and Approach to Modelling of Bearing Capacity Ground Slab. Periodica Polytechnica Civil Engineering, 2017, vol. 61, iss. 4, pp. 972-986. ISSN 1587-3773. DOI: 10.3311/PPci.10688

[22] LABUDKOVA, J. and R. CAJKA. Numerical modeling of the subsoil-structure interaction. Key Engineering Materials. 2016, vol. 691, pp. 333-343.

[23] Dramix ${ }^{\circledR}$ steel fiber concrete reinforcement Bekaert.com, https://www.bekaert.com

[24] MISTRIKOVÁ, Z. and N. JENDZELOVSKY, Static analysis of the cylindrical tank resting on various types of subsoil. Journal of Civil Engineering and Management. 2012, vol. 18, iss. 5, pp. 744-751. DOI: $10.3846 / 13923730.2012 .723346$

\section{About Authors}

Zuzana MARCALIKOVA was born in Havirov. She is Internal Doctoral Student at VSB-Technical University Ostrava. Her research interest involves the modeling of fiber-reinforced composites in interaction with the soil environment.

Zdenka NEUWIRTHOVA was born in Bilovec. She is Internal Doctoral Student at VSB-Technical University Ostrava. Her research interests include numerical modeling using supercomputer, concrete foundation in soil interaction and fiberconcrete modeling.

Radim CAJKA was born in Ostrava. He is Professor at VSB-Technical University Ostrava. His research interest include concrete structures, fibre concrete, foundations, soil - structure interaction, temperature loaded structures, fire resistance, FEM. 